\title{
SOCIAL WORK RESPONSIBILITY TOWARDS STRESS MANAGEMENT
}

\section{Coen Reynolds}

\section{HEALTH AND WELLBEING IN A SOCIAL SERVICE ORGANISATION}

Social work managers (the concept of manager here refers to a director of a social service organisation, head of office or supervisor, or any person who has control over two or more workers) should create and maintain a work environment (Weinbach, 2003:5) that will be conducive to maintaining the health and wellbeing of workers and contribute to the effective delivery of services. Bergh (2004:440) states that "Organisational effectiveness and employee physical and psychological wellbeing should be equally important and are interrelated". Employees, therefore also social workers, should not leave their workplace in a worse state of health than when they arrived there (Williams \& Cooper, 2002:108).

An organisation (in this paper the concept of organisation refers to a non-profit organisation) with a healthy work environment is one in which social workers and other workers experience the following, among other things:

- work satisfaction and a high level of morale;

- good horizontal and vertical communication, working in a team, and mutual respect and confidence in each others' role fulfilment;

- low staff turnover and no excessive absence from work (April, MacDonald \& Vriesendorp, 2000:121; Cooper \& Cartwright, 2002:169; Weinbach 2003:251-260).

In contrast, an unhealthy organisation is one where the staff:

- are continuously in conflict situations and display low productivity, and where there is a large staff turnover;

- have low morale, poor relations among colleagues, complaints about work overload, and feel excluded from the decision-making processes in the organisation (Bergh, 2004:437; Nelson \& Quick, 2006:225).

In an unhealthy work environment social workers can develop work-related stress, which in turn can have a negative influence on the work achievement and health of workers and can thwart the achievement of the objectives of the organisation.

\section{STRESS, STRESSORS AND INTERVENTION STRATEGIES}

For the purposes of this paper occupational stress is defined from a managerial perspective as the interplay between the work environment and the individual, the demands and limitations imposed by the work on individuals, and workers' ability to meet the demands made on them (Kinman \& Jones, 2005:101; Ross \& Altmaier, 1994:11-12).

Not all stress is detrimental to a worker and a limited amount of stress can serve as a stimulus, making work more challenging, more interesting and more worthwhile (Aamodt, 2004:474; McLean \& Andrew, 2000:95). However, managers have the responsibility to identify, prevent and manage work stress that may have a negative influence on workers' work performance and/or health (Department of Labour, 2003:4; Kirby, 2002:314; Stinchcomb, 2004:261).

Nelson and Quick (2006:214) give the following descriptive definition of a stressor: "A stressor, or demand, is the person or event that triggers the stress response". Stressors in an organisation can originate as a result of: (i) work demands, which include matters such as 
work overload and job ambiguity; (ii) interpersonal demands that stem from, among other things, a lack of social support, leadership styles, lack of cohesion and intra-group conflict; (iii) organisational demands and potential stressors caused by, among other things, the organisational structure and climate, organisational politics, decision-making processes and a lack of control over work; and (iv) non-work demands (work/home interface); this comprises stress that is caused by domestic circumstances (Cooper \& Cartwright, 2002:171; Gibson, Ivancevich, Donnelly \& Konopaske, 2006:200; Nelson \& Quick, 2006:217-218; Wainwright \& Calnan, 2002:27).

Symptoms of work stress manifest in workers on the physical level - anxiety, headaches; psychological level - feelings of frustration, depression, low self-image; and behavioural level - over-reacting, aggression, poor interpersonal relationships (Ross \& Altmaier, 1994:140-141; Wainwright \& Calnan, 2002:19).

With regard to stress management interventions, distinctions are made between primary (focus on the organisation), secondary (focus on individual/organisation interface) and tertiary (focus on the individual) intervention strategies (Cooper, Dewe \& O'Driscoll, 2001:189; Giga, Noblet, Faragher \& Cooper, 2003b:158-159). Primary intervention comprises proactive actions directed at addressing stressors arising from the organisational structure. Primary interventions can be directed at changes in job design, structural changes, changes in social systems within the organisation, and changes in management style (Cooper et al., 2001). Secondary intervention strategies "leave the source of the problem unaddressed" (Williams \& Cooper, 2002:124) and the individual is expected to change and to promote his adaptive skills (by means of relaxation training, time management and conflict-resolution strategies) by adapting better in stressful work situations (Ivancevich \& Matteson, 2002:289). The third level of intervention entails the employee undergoing rehabilitation regarding the stress that he/she experiences in the workplace and forms part of Employee Assistance Programmes (Cooper et al., 2001:192; Vigilante, 1993:179-191). Also the tertiary level of intervention does not address workplace stressors directly.

With regard to the secondary level of intervention, Cooper et al. (2001:190) found that "Secondary interventions represent the most common forms of intervention used by organisations to deal with problems of stress management". Criticism against the second and third levels of intervention is that the employee is made responsible for the causes and handling of stress (Cooper et al., 2001:191; Harkness, Long, Bermbach, Patterson, Jordan \& Kahn, 2005:133). It is much easier to place responsibility on "sick" employees to get well than for organisations to take responsibility for determining which ingredients in the work environment are making employees unhealthy in the first place (Stinchcomb, 2004:270).

Research by Giga et al. (2003b) found that in only three out of sixteen research studies on organisational stress did management interventions focus on primary stress intervention. It is clear that empowering the individual worker to handle stressful work situations (second and third levels of intervention) does not succeed in promoting workers' health and wellbeing without having strategies in place which address organisational stressors (Cooper \& Cartwright, 1997, as cited by Giga, Cooper \& Faragher, 2003a).

In the light of the above, an exploratory exposition is now given on the way certain elements of the four basic managerial functions of a social work manager, namely planning, organising, leading and control, can be utilised as potential intervention strategies to address organisational stressors. 


\section{PLANNING AS PRIMARY STRESS INTERVENTION TOOL}

The following components of planning, and strategic planning in particular, that can be applied creatively as primary intervention measures against work stress are singled out:

- the mission of the organisation and the SWOT analysis;

- the organisational objectives and policy of the organisation.

The MISSION of the organisation is usually described in terms of the purpose of the organisation's existence, the nature of service delivery (area of excellence), the client systems served, the core values, uniqueness of the organisation and the management philosophy (Austin \& Solomon, 2000:345-346; Gibson et al., 2006:32; Schuler \& Jackson, 2006:64). It is significant that mission statements do not always directly address the wellbeing and health of employees.

On the primary intervention level social work managers can act innovatively and creatively by making the maintenance and promotion of the wellbeing and health of employees part of the organisation's mission. In this way management accepts responsibility for creating an organisational structure and climate that will not only reduce work stress, but will also accepts direct responsibility for occupational stressors.

During the SWOT analysis (Lewis, Lewis, Packard \& Souflée, 2001:50-52) (analysis of the internal strengths and weaknesses and external opportunities and threats) as part of the strategic planning process, managers will have to take a careful look at stressors in the organisation. During this weakness/threats analysis an evaluation must be made of those stressors that were identified on the basis of a stress audit (see section below on control as primary intervention tool). Unhealthy (stressful) personnel are an internal threat to the successful functioning of an organisation. In their book Managing Beyond the Ordinary Kepner and Likubo (1996:162-163) mention that personnel must be actively involved in helping to investigate and in discussing weak points in the organisation. It goes without saying that ground-level employees must share in the strategic planning process.

The finalising of the mission and SWOT analysis of an organisation is followed by the formulation of organisational objectives (Hellriegel \& Slocum, 1996:140). Social work managers should also formulate strategic objectives regarding the wellbeing and health of employees. Tactical and operational objectives of middle- and lower-level managers should link up with these strategic objectives.

In addition to the formulation of the mission and objectives of the organisation, the policy is explicated, which serves as "guidelines for decision-making" (Shore \& Shore, 1999:44). Therefore there should be a specific policy with guidelines for the handling of work stress on the organisational level (Yin, 2004:608).

The mission, objectives and policy of the organisation therefore form a unit and should indicate where and when the occurrence of work stress should be addressed by the management of the organisation. In this way the management of the organisation commits itself knowingly to creating organisational structures and a climate that will provide for healthy and contented workers.

By maintaining a positive management philosophy of participative management, ground-level workers are given the opportunity to bring forward solutions to address stressful working conditions. Taking the needs of workers into account in turn creates trust (confidence) among staff and management, as well as encouraging open communication (Hellriegel \& Slocum, 
1996). Participative management helps social work managers to shift their thinking from "being judgemental and critical to being helpful and willing to engage in helping employees to solve problems" (Hellriegel \& Slocum, 1996:182, 185).

\section{ORGANISING AS PRIMARY STRESS INTERVENTION TOOL}

Organising as management function implements the mission, objectives, plans and policy of an organisation. Organising comprises, among other things, job design, allocation of responsibilities and tasks to workers, the establishing of sections and relationships among workers in the organisation, the allocation and deployment of resources in the organisation, and the creation of clear communication channels (Brevis, Ngambi, Vrba \& Naicker, 2002:192; Robbins \& Coultar, 1996:355; Weinbach, 2003:191). Any problems that arise in the abovementioned areas which the social worker is unable to deal with could then act as stressors.

It is proposed that social work managers should make a thorough job analysis at least every second year in collaboration with the social workers concerned. A job analysis "defines the jobs within the organization and the behaviours that are necessary to perform those jobs" (Robbins \& Coultar, 1996:379). When such a job analysis indicates that certain workers experience a high level of stress, management should, in terms of their stress-prevention organisational mission, consider management adaptations to reduce work stress in the specific post.

Social work managers can also act proactively with regard to primary stress prevention by purposefully applying the person-environment/organisation fit (PEF) principle (Aamodt, 2004:479; Gibson et al., 2006:208-209). PEF entails the optimum fit between the social worker's abilities and skills and the demands of a job. A misfit in this person-environment fit principle can lead to work stress in the worker. A good person-environment fit is ensured by making known a complete work overview during recruitment of staff. The work overview entails explaining the positive as well as negative realities of the work (Gibson et al., 2006).

Through creative application of collaborative management, a social work manager can establish a decision-making forum in the organisation. Collaborative management is seen as "a process in which two or more individuals with complementary knowledge and skills focus on a common problem or issue (like work stress) and work together to create a resolution neither of them could achieve alone" (Kepner \& Likubo, 1996:19; Schuler \& Jackson, 2006:27). Mutual trust is promoted, as well as open and reliable communication. Trust is an important catalyst to reveal stress, while collaborative management has a positive influence on the health and wellbeing of workers (Department of Labour, 2003:16; Giga et al., 2003a:2).

A further primary intervention strategy that arises from the organising function of a manager is the establishment of an advocacy committee (Turner \& Shera, 2005:84-85). Ground-level social workers can bring their problems regarding job overload, job ambiguity, etc. to the committee. The committee then acts on behalf of the staff member with the management committee, and on an organisational level attention is devoted to the way that specific organisational stressors can be eliminated.

\section{LEADING AS PRIMARY INTERVENTION TOOL}

As leaders, social work managers can create a healthy organisational climate, thereby minimising stressors by, among other things, promoting teamwork in the organisation and by 
developing a value system in which managers and social workers have mutual respect, understanding and confidence in each other's roles (Weinbach, 2003).

Managers must stay in touch with the feelings and needs of their staff. By applying the management principle of "managing by wandering around", managers can converse with personnel about their work, thereby identifying potential stressors (Weinbach, 2003:253-255). By coming to the level of his/her ground-level workers and by listening and observing, the manager can identify potential symptoms of work stress among workers by asking the following questions, derived from Rudyard Kipling's work:

- I keep six honest serving men,

- They taught me all I know,

- Their names are WHAT and WHY and WHEN,

- And WHO and WHERE and HOW

- (Kepner \& Likubo, 1996:98-99).

Managers should also develop skills by becoming aware of their own cognitive processes (April et al., 2000:13), and by also being aware of the way their actions can influence the lives of other people and the environment (Hauer, 2006:3). Being aware of yourself and other workers is the starting point of good leadership. In this regard April et al. (2000:xv) state that (self-)awareness in leadership is a critical component in the role of a manager in the new millennium. They add: "As a leader it is ... critical to be aware on a number of fronts, not only of yourself, but of others, as well as of the context in which you operate". Managers should therefore be aware when social workers display stress-related behaviour. Then, on a primary intervention level, they should first seek for possible stressors that may be present in their management style or organisational structure and climate (April et al., 2000).

The opposite of this awareness is blind spots that may occur in the management style of managers (Visser \& Denton, 2006:2). Blind spots refer to the areas where the manager displays "unconscious incompetence". Blind spots are catastrophic for organisations, because they combine arrogance and weakness. Examples of blind spots are, among others, the need to always be right; claiming good ideas and success without deserving it; engaging in political manoeuvring and generating unnecessary conflict; low level of concern for the human element (Visser \& Denton, 2006).

\section{CONTROL AS PRIMARY INTERVENTION TOOL}

The control function of a manager forms an integral part of the planning, organising and leading function. The control function ensures that the resources in the organisation are utilised effectively and appropriately, and also that the behaviour and service delivery of workers are in accordance with the mission, objectives and policy of the organisation. The control process comprises (i) establishing standards of work performance; (ii) the measuring of work performance; (iii) the evaluation of any deviation from the set standards; and (iv) taking corrective actions (Brevis et al., 2002). Workers often experience control negatively because often good achievement is not acknowledged (Hellriegel \& Slocum, 1996:585; Noe, Hollenbeck, Gerhart \& Wright, 2006:329). Workers experience performance appraisal as stressful because performance appraisal systems are often not valid, reliable and free of bias (McKenna, 2003:546-548). A manager with a well-developed sense of awareness should more easily be able to identify any stress-related behaviour among workers through the performance appraisal and address it by means of organisational changes. 
Organisational politics often play a role in performance appraisal when it must be decided who must be assessed and who gets which promotion. These aspects can lead to interpersonal conflict among workers and can eventually lead to stress. Social work managers can be proactive in this regard on the level of primary intervention and can minimise the politicising of performance appraisal by "developing and communicating clear and specific goals and standards, linking performance to results, and providing employees with periodic, accurate feedback on their performance" (Hellriegel \& Slocum, 1996:389).

A final primary stress prevention strategy that social work managers can employ by means of their control function is introducing an annual stress audit. A stress audit entails "requiring individual employees to give close consideration to the way they feel about work pressures" (Palmer, Cooper \& Thomas, 2001:378; Williams \& Cooper, 2002:112). A stress audit enables managers to indicate to the management team which organisational structural factors are causative stressors (Williams \& Cooper, 2002). With regard to a proactive stress audit, social work managers can note the following aspects that generate potential stressors: organisational climate, demands as a result of work overloading, the degree of autonomy that the worker has in his or her work, relationships among colleagues, what influence organisational change has on the health and wellbeing of the staff, role fulfilment (is there confusion about roles?) and role conflict (is there a social support system among workers?) (Akabas \& Farrell, 1993; Palmer et al., 2001).

\section{CONCLUSION}

It can thus be concluded that organisational stressors play a major role in the life of workers in non-profit organisations and it is imperative that stressors should be addressed by social workers in a managerial position. It is recommended that organisational stress intervention should start at the primary intervention level. Furthermore, the managerial functions of planning, organising, leading and control should be actively used by managers as "intervention" tools in order to prevent (as far as is humanly possible) potential situations, managing styles or managerial and interpersonal behaviour that may precipitate stressors.

It is recommended that, in their yearly (biannual) strategic planning sessions, welfare organisations should address the aspect of "organisational stress and stressors" as part of their agenda. During their SWOT analysis they can identify and discuss all the organisational stressors that were manifested during the current year and make the necessary rectifications and adjustments where applicable for the next year. Special attention should be given to the principles of person-environment fit during the organising of the workload and job design of workers. The more delicate and in a way controversial aspect to address and rectify is the leadership style of managers as a potential stressor. Here welfare organisations can utilise an external consultant in stress management to facilitate the discussion process, negotiations and coaching among workers and managers in order to address the management styles of managers as potential stressors. All of the aforementioned interventions culminate in a stress audit that is part of the controlling managerial function.

It is thus evident that managers have a responsibility to create a friendly and healthy organisational climate and culture in order to promote the wellbeing of their workers. Also, by engaging workers in a participative managing process in their organisation will they ensure, among other things, work satisfaction and a high morale amongst the workers.

Lastly, it is recommended that more research should be done on intervention on a primary level in addressing organisational stressors and attention should be given to the development of a 
Manager Assistance Programme (MAP) in order to empower managers further in their management tasks within the context of workers' health and wellbeing.

\section{REFERENCES}

AAMODT, M.G. 2004. Applied industrial/organizational psychology. London: Thomson Wadsworth.

AKABAS, S.H. \& FARRELL, B.F. 1993. Prevention: an organizing concept for workplace services. In: KURZMAN, P.A. \& AKABAS, S.H. (eds) Work and well-being. The occupational social work advantage. Washington DC: NASW Press.

APRIL, K.A., MacDONALD, R. \& VRIESENDORP, S. 2000. Rethinking leadership. Cape Town: University of Cape Town Press.

AUSTIN, J.A. \& SOLOMON, J.R. 2000. Managing the planning process. In: PATTI, R.J. (ed) The handbook of social welfare management. Thousand Oaks. Sage Publications.

BERGH, Z. 2004. Work adjustment. In: BERGH, Z.C. \& THERON, A. (eds) Psychology in the work context. Oxford: Oxford University Press.

BREVIS, T., NGAMBI, H.C., VRBA, M.J. \& NAICKER, K.S. 2002. Controlling. In: SMIT, P.J. \& CRONJE, G.J. de J. (eds) Management principles: a contemporary edition for Africa. Lansdowne: Juta.

COOPER, C.L. \& CARTWRIGHT, S. 2002. Healthy mind; healthy organization - a proactive approach to occupational stress. Human Relations, 47(4):455-471. Reprinted in COOPER, C.L. (ed), Fundamentals of Organizational Behavior, 3. London: Sage Publications.

COOPER, C.L., DEWE, P.J. \& O'DRISCOLL, M.P. 2001. Organizational stress: a review and critique of theory, research, and applications. Thousand Oaks: Sage Publications.

DEPARTMENT OF LABOUR. 2003. Healthy work: managing stress in the workplace. [Online] Available: http://www.workinfo.govt.nz [Accessed: 28/08/2006].

GIBSON, L.G., IVANCEVICH, J.M., DONNELLY, J.H. \& KONOPASKE, R. 2006. Organizations: behavior structure processes. Boston: McGraw-Hill/Irwin.

GIGA, S.I., COOPER, C.L. \& FARAGHER, B. 2003a. The development of a framework for a comprehensive approach to stress management interventions at work. International Journal of Stress Management, 10(4):280-296.

GIGA, S.I., NOBLET, A.J., FARAGHER, B. \& COOPER, C.L. 2003b. The UK perspective: a review of research on organisational stress management interventions. Australian Psychologist, 38(2):158-164.

HARKNESS, A.M.B., LONG, B.C., BERMBACH, N., PATTERSON, K., JORDAN, S. \& KAHN, H. 2005. Talking about work stress: discourse analysis and implications for stress interventions. Work \& Stress, 19(2):121-136.

HAUER, S. 2006. Success blind spots: get out of your own way. [Online] Available: http://www.refresher.com/!srhblind.html [Accessed: 22/09/2006].

HELLRIEGEL, D. \& SLOCUM, J.W. 1996. Management. Cincinnati: South-Western College Publishing. 
IVANCEVICH, J.M. \& MATTESON, M.T. 2002. Organizational behavior and management. Boston: McGraw-Hill/Irwin.

KEPNER, C.H. \& LIKUBO, H. 1996. Managing beyond the ordinary. New York: Amacom.

KINMAN, G. \& JONES, F. 2005. Lay representations of workplace stress: what do people really mean when they say they are stressed? Work \& Stress, 19(2):101-120.

KIRBY, P. 2002. Managing stress for optimal outcomes. Nephrology Nursing Journal, 29(3):314.

LEWIS, J.A., LEWIS, M.D., PACKARD, T. \& SOUFLÉE, F. 2001. Management of human service programs. London: Brooks/Cole.

McKENNA, E. 2003. Business psychology and organisational behaviour: a student's handbook. New York: Psychology Press Ltd.

McLEAN, J. \& ANDREW, T. 2000. Commitment, satisfaction, stress and control among social services managers and social workers in the UK. Administration in Social Work, 23(3/4):93117.

NELSON, D.L. \& QUICK, J.C. 2006. Organizational behavior: foundations, realities \& challenges. USA: Thomson South-Western.

NOE, R.A., HOLLENBECK, J.R., GERHART, B. \& WRIGHT, P.M. 2006. Human resource management: gaining a competitive advantage. New York: McGraw-Hill Irwin.

PALMER, S., COOPER, C. \& THOMAS, K. 2001. Model of organisational stress for use within an occupational health education/promotion or well-being programme - a short communication. Health Education Journal, 60(4):378-380.

ROBBINS, S.P. \& COULTAR, M. 1996. Management. New Jersey: Prentice-Hall.

ROSS, R.R. \& ALTMAIER, E.M. 1994. Intervention in occupational stress. London: Sage Publications.

SCHULER, R.S. \& JACKSON, S.E. 2006. Human resource management: international perspectives. Singapore: Thomson Wadsworth.

SHORE, E.A. \& SHORE, H.H. 1999. Early intervention and administration: bridging the gap for social workers. Infants and Young Children, 12(1):43-58.

STINCHCOMB, J.B. 2004. Searching for stress in all the wrong places: combating chronic organizational stressors in policing. Police Practice and Research, 5(3):259-277.

TURNER, L.M. \& SHERA, W. 2005. Empowerment of human service workers: beyond intraorganizational strategies. Administration in Social Work, 29(3):79-94.

VIGILANTE, F.W. 1993. Work: its use in assessment and intervention with clients in the workplace. In: KURZMAN, P.A. \& AKABAS, S.H. (eds) Work and well-being: the occupational social work advantage. Washington DC: NASW Press.

VISSER, R. \& DENTON, J.M. 2006. Executive blind spots. Unpublished paper. University of Stellenbosch, Business School, South Africa.

WAINWRIGHT, D. \& CALNAN, M. 2002. Work stress: the making of a modern epidemic. Buckingham: Open University Press. 
34

WEINBACH, R.W. 2003. The social worker as manager: a practical guide to success. Boston: Allyn \& Bacon.

WILLIAMS, S. \& COOPER, L. 2002. Managing workplace stress. New York: John Wiley \& Sons Ltd.

YIN, R.T. 2004. Innovations in the management of child protection workers: building worker resilience. Social Work, 49(4):605-608.

Dr Coen Reynolds, Department of Social Work, Hugenote College, Wellington, SouthAfrica. 